\title{
UTILIZATION OF AUDIO-VISUAL MEDIA BASED ON LOCAL WISDOM AS TEACHING AND LEARNING MEDIA ON ELEMENTARY SCHOOL EDUCATION STUDENTS DURING THE COVID-19 PANDEMIC
}

\author{
Delora Jantung Amelia ${ }^{1^{*}}$, Ima Wahyu Putri Utami ${ }^{2}$, Bahrul Ulum ${ }^{3}$ \\ ${ }^{1,2,3}$ University Of Muhammadiyah Malang \\ delorajantung@umm.ac.id
}

DOI: https://doi.org/10.21107/Widyagogik/v8i2. 8588

Received September 17, 2020; Revised November 06, 2020; Accepted November 17, 2020

\section{Abstract}

The pandemic that is being felt all over the world today known as the COVID-19 pandemic is a disaster that disrupts all segments of the earth without exception education. The entire center of the crowd, be it tourist attractions, market malls to schools and colleges, decided to close. With the COVID-19 virus in Indonesia, it has had a huge impact on the education system in Indonesia. In Indonesia all learning activities are directed towards online learning which has advantages and disadvantages. Learning carried out in elementary schools also uses online / distance learning through parental guidance. The purpose of this study is to analyze the use of audio visual media based on local wisdom as. The purpose of this study was to describe the use of audio-visual media based on local wisdom as a form of learning for PGSD students during the Covid19 period, learning problems using audio-visual media and how to solve problems. The results of this study resulted in the conclusion that learning using audio-visual media has several advantages, including learning using audio-visual media based on local wisdom that can facilitate learning activities, get to know local wisdom of the local area. Learning using audio-visual media based on local wisdom also has several problems, including difficult to understand without a companion. The problem of learning using audio-visual media based on local wisdom can be overcome by the existence of a manual on the use of media and the assistance that also facilitates learning activities.

Keywords - Audio Visual Media, Local Wisdom, Teaching and learning 

33 Utilization of Audio-Visual Media Based on Local Wisdom as Teaching and Learning Media on Elementary School Education Students During The Covid-19 Pandemic

Delora Jantung Amelia, Ima Wahyu Putri Utami, Bahrul Ulum

\section{Introduction}

The pandemic that is being felt all over the world today known as the COVID-19 pandemic is a disaster that disrupts all segments of the earth without exception Education. The entire center of the crowd, be it tourist attractions, market malls to schools and colleges, decided to close. With the COVID-19 virus in Indonesia, it has had a huge impact on the education system in Indonesia. In Indonesia all learning activities are directed towards online learning which one has strengths and weaknesses. Persell, 1979 stated that learning activities are a policy tool as an effort to increase knowledge and skills, but in this disaster learning activities cannot be carried out face-to-face, Baharin, 2020 revealed that in Indonesia, learning activities carried out in schools greatly affect productivity. Learning activities are carried out in a mixed manner with the term blended learning which combines synchronous and asynchronous learning that requires media support.

Learning media, the quality of learning can be achieved as planned. Arsyad, 2006 explained that learning media can fulfill three main functions that can be used, namely to motivate interest in learning, to present information young and to explain something that is not well described. Sudrajat, 2011 revealed that media is a physical means to convey material content such as books, films, videos and so on. Prasetyo, 2007 with the existence of learning media has special benefits, among others, the delivery of material can be uniformed, learning activities become clearer and more interesting, and can foster a positive attitude towards the material being taught. With the support of learning media that is oriented to local wisdom, it can make learning activities easier.

Sriyatin, 2013 local wisdom is basically the values of goodness from local culture that are already known by the local community and have received approval by the local community. Salimi, 2016 local wisdom is an investment that gives students the skills, abilities and qualities themselves in facing the global world without leaving an identity. Basically, in the field, there are many teachers who have not integrated local wisdom in learning so that the learning objectives have not been achieved and they also do not know local wisdom in their environment. By getting to know local wisdom and implementing local wisdom in learning activities will facilitate the learning process because then students will get to know the learning activities carried out more closely. Therefore, PGSD students are required to be able to create and apply learning media based on local wisdom according to their place of residence and then applied to students.

The use of audio-visual media in learning activities can make it easier, make participants more earnest Sayidiman, 2012 in the article revealed that the use of audiovisual media can stimulate student interest in dance courses and create a conducive learning climate. Najmi, 2017 explains in his article the use of audio visuals can increase interest in learning. This study aims to apply audio-visual media based on local wisdom that can be used in learning activities during the pandemic, starting from planning, implementing learning, skills in making and using local wisdom-based audio visual 
media and to find out the advantages and disadvantages of implementing online learning.

\section{Method}

This type of research uses descriptive qualitative research, the research used to examine a natural object condition in which a researcher is a key instrument. Sugiyono, 2009. Descriptive research aims to describe a variable both independent and controlled variables. In this study, the data collected in the form of a questionnaire distributed to 2 classes of students totaling 100 people. Data taken through Google Form, WhatsApp which is the answer to the use of learning media as a learning effort. This research was conducted with a qualitative approach because the focus of research is related to the use of audio visual media. The qualitative approach was chosen because the problems were unclear, holistic, complex and dynamic.

The data collection technique used was a research instrument. The main instrument in this research is the researcher himself who acts as an observer, interpreter and data analyzer. The research instrument used interview guidelines and observation sheets. Interview guidelines are used to obtain data related to lesson planning, supporting and inhibiting factors in local wisdom-based thematic learning. Harsono, 2008 qualitative research is also called naturalistic research, where the results of research are obtained from conditions in the field that are natural, natural, natural and there is no manipulation. Data is a record of everything that is heard, seen and experienced by data collectors and then reflected in the report.

Moleong, 2006 revealed that the data collected is in accordance with the research focus, namely the use of audio-visual media based on local wisdom. The type of data in this research is divided into two types, namely primary data and secondary data. Primary data were obtained in the form of verbal or words related to the use of audiovisual media based on local wisdom. Technique methods used in this research are interviews, observation and documentation study.

\section{Result and Discussion}

Based on the results of the survey filling out a questionnaire given to PGSD students, data can be obtained that are described in the discussion

\section{Use of audio-visual media based on local wisdom}

Measuring the use of audio-visual media made by PGSD students as an effort to deliver material during the pandemic period obtained the following causes: 
35 Utilization of Audio-Visual Media Based on Local Wisdom as Teaching and Learning Media on Elementary School Education Students During The Covid-19 Pandemic

Delora Jantung Amelia, Ima Wahyu Putri Utami, Bahrul Ulum

Tabel 1 Table 1 Percentage of Questionnaire Results Using Audio Visual Media Based on Local Wisdom

\begin{tabular}{|c|c|c|c|c|c|}
\hline \multirow[t]{2}{*}{ No } & \multirow[t]{2}{*}{ description } & \multicolumn{3}{|c|}{ class } & \multirow[t]{2}{*}{ average } \\
\hline & & C & D & E & \\
\hline 1 & $\begin{array}{l}\text { The use of audio visual media facilitates } \\
\text { the delivery of material to students }\end{array}$ & $92 \%$ & $90 \%$ & $93,8 \%$ & $91,9 \%$ \\
\hline 2 & $\begin{array}{l}\text { The use of audio-visual media based on } \\
\text { local wisdom can make it easier to } \\
\text { introduce local culture }\end{array}$ & $88 \%$ & $87,3 \%$ & $90,1 \%$ & $88,4 \%$ \\
\hline 3 & $\begin{array}{l}\text { Evaluating the relevance of the material is } \\
\text { easier }\end{array}$ & $78 \%$ & $74 \%$ & $82 \%$ & $78 \%$ \\
\hline 4 & $\begin{array}{l}\text { The use of technology makes learning } \\
\text { more fun }\end{array}$ & $92,1 \%$ & $89 \%$ & $93 \%$ & $91,3 \%$ \\
\hline 5 & $\begin{array}{l}\text { The use of digital media makes } \\
\text { collaboration easier in learning activities }\end{array}$ & $87,8 \%$ & $88 \%$ & $84 \%$ & $86.6 \%$ \\
\hline 6 & $\begin{array}{l}\text { The use of audio-visual media based on } \\
\text { local wisdom can facilitate interaction with } \\
\text { local residents }\end{array}$ & $50,8 \%$ & $70 \%$ & $68 \%$ & $63 \%$ \\
\hline 7 & $\begin{array}{l}\text { The use of audio visuals can make the } \\
\text { work of students easier }\end{array}$ & $70,8 \%$ & $81,8 \%$ & $80 \%$ & $77.5 \%$ \\
\hline \multirow[t]{2}{*}{8} & $\begin{array}{l}\text { The use of audio visual media further } \\
\text { enhances learning activities }\end{array}$ & $93,4 \%$ & $92,1 \%$ & $94 \%$ & $93.1 \%$ \\
\hline & Avarage & $81,6 \%$ & $84,02 \%$ & $85,6 \%$ & $83,7 \%$ \\
\hline
\end{tabular}

According to table 1, information related to the application of the use of audiovisual media based on local wisdom of S1 PGSD is very high at $83.7 \%$. With the results of the discussion that students applying the use of visual media based on local wisdom can facilitate the delivery of material, this is reinforced by the average results in three classes which reach 91.9\%, this is in accordance with Miarso, 2011 which states that using audio-visual media can stimulate the brain so that it can overcome the limitations of experience that each individual has when learning activities take place. The use of audio-visual media can facilitate the introduction of local culture with $88.4 \%$ results, this is due to the presence of audio-visual media, the material is more complete, more uniform and the material can reach an event or object in accordance with Rohman, 2013 's opinion. it was easier and more enjoyable with a mean yield of $78 \%$ and $91.3 \%$. The use of audio-visual media can also facilitate collaboration in learning activities with an average result of $86.6 \%$. The use of audio visuals can also facilitate students' work with an average of $77.5 \%$ and the use of audio-visual media can also increase student learning activities as evidenced by a percentage of $93.1 \%$. 
Table 2 Percentage of Questionnaire Results on the Problems of Using Audio Visual Media Based on Local Wisdom

\begin{tabular}{lllccc}
\hline No & \multicolumn{1}{c}{ description } & \multicolumn{3}{c}{ Class } & Average \\
\cline { 3 - 4 } & & C & D & E & \\
\hline 1 & $\begin{array}{l}\text { The use of audio visual media is difficult } \\
\text { for students to understand without the } \\
\text { assistance of other people. }\end{array}$ & $88 \%$ & $83,8 \%$ & $91 \%$ & $87,6 \%$ \\
& & & & \\
\hline 2. & $\begin{array}{l}\text { Students need tools to be able to play } \\
\text { videos }\end{array}$ & $78,8 \%$ & $81,8 \%$ & $84 \%$ & $81,5 \%$ \\
\hline 3. & $\begin{array}{l}\text { Students are less constructive when } \\
\text { learning to use audio-visual media without } \\
\text { a companion. }\end{array}$ & $82 \%$ & $83 \%$ & $81 \%$ & $82 \%$ \\
\hline \multicolumn{1}{c}{ Rerata } & $79,7 \%$ & $80,4 \%$ & $83,2 \%$ & $81 \%$ \\
\hline
\end{tabular}

Table 2 provides information that the results of the questionnaire lack of use of audio-visual media based on local wisdom in class, C, D and E provide information that the use of audio-visual media is difficult to understand if used without someone else's companion gives an average class of $87.6 \%$ which means Students in elementary grade level learn difficult when using audio-visual media without a companion. Students become lazy to learn when using audio-visual media not in accordance with the results of the questionnaire obtained, which means that students prefer to learn using audiovisual media rather than conventional. Students need aids when learning to use visual audiences which are stated with a response of $81.5 \%$, which means that audio visual media cannot be used optimally if they do not use other tools. Students taught by PGSD students are less concentrated when learning using audio-visual without a companion. The problem of implementing learning using audio-visual media based on local wisdom can also be overcome with several solutions including the following:

Table 3 Presets on How to Overcome Learning Problems Using Audio Visual Media Based on Local Wisdom

\begin{tabular}{|c|c|c|c|c|c|}
\hline \multirow[t]{2}{*}{ No } & \multirow[t]{2}{*}{ description } & \multicolumn{3}{|c|}{ Class } & \multirow[t]{2}{*}{ Average } \\
\hline & & C & D & $E$ & \\
\hline 1 & $\begin{array}{l}\text { Students use guidebooks when learning } \\
\text { using audio visual media based on local } \\
\text { wisdom. }\end{array}$ & $92 \%$ & $88,8 \%$ & $92 \%$ & $90,9 \%$ \\
\hline \multirow[t]{2}{*}{2} & $\begin{array}{l}\text { Students are accompanied when learning } \\
\text { using audio visual media based on local } \\
\text { wisdom. }\end{array}$ & $88,9 \%$ & $90 \%$ & $88 \%$ & $88,9 \%$ \\
\hline & Rerata & $90,4 \%$ & $89,4 \%$ & $90 \%$ & $89,9 \%$ \\
\hline
\end{tabular}

From the data in table 3 it can be explained that learning problems using audio visual media based on local wisdom using audio visual media will be easier to use a 
guidebook because with a guidebook, students will learn systematically and conceptually according to the instructions in the guidebook, this is proven with an average result of $90.9 \%$, which means that you really need instructions in doing it. Students also find it easier to learn using learning media if there is a companion because the companion makes it easier for students to understand this with a percentage of $88.9 \%$.

\section{Conclusion}

The conclusions that can be drawn by researchers related to research on the application of the use of audio-visual media based on local wisdom as a form of learning for PGSD students during the Covid 19 period are as follows:

1) Learning using audio-visual media has several advantages, including learning using audio-visual media based on local wisdom that can facilitate learning activities, get to know local wisdom in the local area, be more fun, and can increase learning motivation.

2) Learning using audio-visual media based on local wisdom also has several problems including difficult to understand without a companion, students need aids when using audio-visual media, and students find it difficult to learn without a companion.

3) The problem of learning using audio-visual media based on local wisdom can be overcome by the existence of a manual on the use of media and the assistance also facilitates learning activities.

\section{References}

Arsyad. 2006. Media Pembelajaran. Jakarta: Rineka Cipta

Caroline Hodges Persell, 1979. Education and Inequality, The Roots and Results of Strattification in America's Schools. United States Of America: The Free Press.

Gall, dkk. 2003. Educational Research.An Introduction (7th ed.).New York: Person Education Inc.

Harsono. 2008. Etnografi Pendidikan Sebagai Desain penelitian Kualitatif. Surakarta: Universitas Muhammadiyah Surakarta

Miarso, Yusufhadi. 2004. Menyemai Benih Teknologi Pendidikan. Jakarta: Kencana

Moh Salimi. 2016. Pengembangan Pendidikan Karakter Bangsa Berbasis Kearifan Lokal Dalam Era Mea.

Moeleong. J, Lexy. 2006. Metodelogi Penelitian Kualitatif. Bandung: PT Remaja Rosdakarya

Rohman, Muhammad dan Sofan Amri. 2013. Strategi dan Desain Pengembangan Sistem Pembelajaran. Jakarta: Prestasi Pustakaraya. 
Sayidiman. 2012. Penggunaan Media Audio Visual Dalam merangsang Minat Mahasiswa Terhadap Mata Kuliah Seni Tari. Jurnal Publikasi Pendidikan Volume II No 1 FebuariMei 2012.

Sigit Prasetyo, 2007. Pengembangan Pembelajaran Dengan menggunakan Multimedia Interaktif Untuk Pembelajaran Yang Berkualitas. Semarang: UNNES

Sriyatin. 2013. Penanaman dan Pengembangan Pendidikan Karakter Berbasis Kearifan Budaya Lokal Di SDN.

Sudrajat. 2011. Dasar-dasar Penelitian IImiah. Bandung: Pustaka Setia 